\begin{tabular}{|c|c|c|}
\hline Beitr. Ent. & Keltern & ISSN 0005-805X \\
\hline $\mathbf{6 1}(2011) 2$ & S. $357-370$ & 10.11 .2011 \\
\hline
\end{tabular}

\title{
New and poorly known Tineidae from the Western Palaearctic
}

\section{(Lepidoptera)}

With 30 figures

REINHARD GAEDIKE

\section{Summary}

As the result of the study of tineid material, which was collected in numerous countries of Western Palaearctic, were etablished first records for 8 countries, two of them are first records for Europe. The material contains four species, which are described as new species: Neurothaumasia tenuipennella, Neurothaumasia tunesiella, Infurcitinea corleyi and Ateliotum larseni. From Matratinea rufulicaput SzIraKI \& Szöcs, 1990 and Anomalotinea gardesanella (HARTIG, 1950) were described and illustrated the female genitalia for the first time, from Elatobia bugrai Kосак, 1981 were described and illustrated the male genitalia for the first time. The examination of the type series of Euplocamus anthracinalis amanalis OsTHELDER, 1936 shows, that this taxon is a new synonym of Euplocamus delagrangei Ragonot, 1895. There was designated and selected the lectotype for Euplocamus anthracinalis amanalis OstHeLder, 1936.

\section{Zusammenfassung}

Im Ergebnis der Untersuchung von Tineiden-Material, welches in zahlreichen Ländern der Westpaläarktis gesammelt wurde, konnten für 8 Länder Erstfunde festgestellt werden, zwei davon sind Erstfunde für Europa. Das Material enthielt vier Arten, die als neue Arten beschrieben werden: Neurothaumasia tenuipennella, Neurothaumasia tunesiella, Infurcitinea corleyi und Ateliotum larseni. Von Matratinea rufulicaput SzIraki \& Szöcs, 1990 und Anomalotinea gardesanella (HARTIG, 1950) werden erstmals die weiblichen Genitalien abgebildet und beschrieben, von Elatobia bugrai KocaK, 1981 werden erstmals die männlichen Genitalien abgebildet und beschrieben. Die Untersuchung der Typenserie von Euplocamus anthracinalis amanalis OstheldeR, 1936 zeigte, dass es sich hierbei um ein Synonym von Euplocamus delagrangei RaGonot, 1895 handelt. Es wurde der Lectotypus für Euplocamus anthracinalis amanalis OsTHELDER, 1936 ausgewählt und festgelegt.

\section{Key words}

Western Palaearctic; Tineidae; new species; new records; new synonymy

\section{Introduction}

The determination of tineids, collected by several colleagues in various countries of western Palaearctic together with the study of still undetermined material from several museum collections increases our knowledge about the distribution of the members of this family and make it possible to describe some hitherto unknown species, for some taxa the hitherto unknown sex and to establish a new synonym.

The studies material is deposited in various museums or in the private collections of the collectors. 


\title{
Abbreviations
}

The abbreviations of the institutional collections, in which the studies material is deposited, follow the list "Insect and Spider Collections of the World" from the Bishop Museum/Honolulu (http://hbs.bishopmuseum.org/codens).

\author{
coll. Baldizzone Giorgio Baldizzone /Italy, Asti \\ coll. Baraniak Edward Baraniak /Poznán, Poland \\ coll. Corley Martin F. V. Corley /Faringdon, U.K. \\ coll. Keller Rudolf Keller / Sulzemoos, Germany \\ coll. Larsen Knud Larsen /Dyssegard, Denmark \\ coll. Richter IVAN Richter/Prievidza, Slovakia \\ coll. Roweck Hartmut Roweck /Kiel, Germany \\ coll. Wauer Sven Wauer / Ebersbach, Germany \\ FMNH Finnish Museum of Natural History (Lauri KaIla), Helsinki, Finland \\ SDEI Senckenberg Deutsches Entomologisches Institut, Müncheberg, Germany \\ USNM National Museum (Don S. DAvis), Washington D. C., United States \\ ZFMK Zoologisches Forschungsmuseum Alexander Koenig (Dieter STÜNING), Bonn, Germany \\ ZMHB Museum für Naturkunde der Humboldt-Universität (Wolfram MeY), Berlin, Germany \\ ZMUC Zoological Museum (Ole Karsholt), Copenhagen, Denmark
}

\section{Acknowledgments}

I am thankful to my collegues for the courtesy to make it possible for me to study the tineid material. Special thank to Christian Kutzscher for making color pictures, and to Andrew Liston for linguistic corrections.

\section{Systematics}

\section{Dryadaula minuta GAEDIKE, 2007}

\section{Material:}

Greece: $2 o^{\top} o^{\top}$ Rhodos, 5 m S. Rodos, 250 m, 4.-8.vii.2000, leg. M. Fibiger; ZMUC: First record for Europe, the species was previously known only from Turkey (type location).

\section{Euplocamus delagrangei RAGONOT, 1895}

Euplocamus anthracinalis amanalis OSTHELDER, 1936, syn. n.

OSTHELDER described this taxon as subspecies amanalis of Euplocamus anthracinalis on the base of three specimens without any designation of holotype. OsTHELDER wrote: “... Es liegen 3 von YD [Yüksek-Dagh], 1.-15.V.[19]33 u. [19]34 vor, ...”. Two of them are located in his collection, which is housed now in the Zoologische Staatssammlung Munich. Through the kindness of my colleague Andreas Segerer it was possible to examine these types. The examination shows, that 
the specimens belong to Euplocamus delagrangeri RAGONOT, 1895, and Euplocamus anthracinalis amanalis Osthelder, 1936 is now a new synonym. For fixation of this synonymization one specimen is designated as lectotype. It bears the following labels:

1. "Amanus, s. Dül-Dül Dagh (Jeschildere) A[nfang]. V. [19]34;” 2. [red paper] "Eupl. Anthracinals ssp. Amanalis Osth. o Type;” 3. "coll. Osthelder;” 4. Euplocamus delagrangeri Ragonot o*, Lectotypus, des. R. Gaedike 2010.”

The labels of paralectotype are:

1. "Syria s. Amanus s. Düldül Dagh (Yüksek Dagh) Jeschil dere 15.V.[19]33;” 2. "ssp. amanalis Osth. Cotype ơ;" 3. "coll. Osthelder;" 4. "Euplocamus delagrangei Ragonot o", Paralectotypus des. R. GAEDIKE 2010.”

\section{Nemapogon reisseri Petersen \& GAEDIKe, 1983}

\section{Material:}

Turkey: $1 \sigma^{\star}$, Prov. Muglia, Marmaris, Yalanci Bogazi, $10 \mathrm{~km}$ südöstl. Marmaris, 19.ix.2003, leg. et coll. R. KeLLER. First record outside of Europe.

Previously known only from Greece (incl. Crete and several other smaller islands).

\section{Triaxomasia caprimulgella (STAINTON, 1851)}

\section{Material:}

France: Corse, 1 ๙ $^{\star}, 3$ km N Monacia d'Aulcènne, 200 m, 24.vi.2005, leg. B. SkulE; ZMUC. First record for Corse.

The recent records fill up the distribution gap in the Mediterranean region. Previously known from Iberian Peninsula through France and Italy to Greece, eastwards through Romania to Ukraine, northwards through Switzerland, Germany, Czech Republic and Slovakia to Denmark and Sweden.

The two new species, which were described below, differs from the other known members of genus Neurothaumasia by having head brush only in the middle of the head, the basal part from neck to insertion antennae and the apical part above palpi is covered by flat scales. In the male genitalia gnathos arms are absent.

\section{Neurothaumasia tenuipennella sp. $\mathbf{n}$.}

\section{Material:}

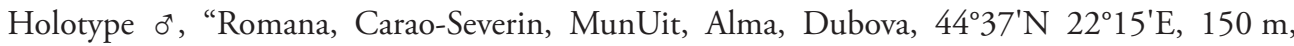
15.vii.2005, leg. B. Skule, C. Hvird \& E. Vesterhede;" “Coll. ZMUC, Copenhagen, DK;" "Gen.präp. [genitalia slide] Gaedike Nr. 7100;" "Holotypus ơ Neurothaumasia tenuipennella

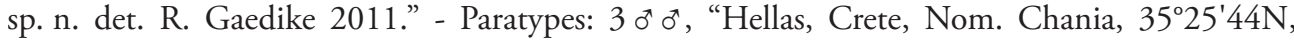
235'ㄹ'22E, Skines, 75 m, 5.-11.vi.2004, leg. B. Skule, C. Hvind \& E. Vesterhede;" "Coll. ZMUC, Copenhagen, DK;" "Gen.präp. [genitalia slide] GAedike Nr. 6556, 6694, 7106;" ZMUC (two specimens); SDEI (one specimen); 1 o , "YU, Croazia, KRK, Skrpcici (W.L.), 4.viii.1977, 
leg. BAldizzone;", "Bldz PG n 13806 o ;" coll. Baldizzone; 1 ㅇ, "GREECE, Lesvos, Skala Kallonis, Malemi hotel, $19^{\circ} 12^{\prime} 33 \mathrm{~N}, 26^{\circ} 12^{\prime} 13 \mathrm{E}, 11 .-13 . v i .2009$, L. KaIla \& J. Kullberg leg.”” "Gen.präp. [genitalia slide] GaEdike Nr. 7235;" FMNH; 1 \% , 1 specimen without abdomen, "[location unreadable], 20.5.[19]14;" "Anastase Alfieri Collection 1965;" "Coll. Alfieri Egypte;"“Gen.präp. [genitalia slide] GaEdike Nr. 4931;” USNM.

\section{Description (Figs 1-2):}

Wingspan 8-9 mm; head brush dark brown-grey, nearly black, apically lighter, scales from neck to insertion of antennae and above palpi flat; labial palpi outside brown-grey, inside creamy, second segment apically with some bristles; thorax and tegulae dark brown-grey; forewing narrow, dark brown-grey, females at $1 / 2$ on dorsum and before apex with short yellowish stripe, by males the stripe before apex nearly unvisible; hindwing dark grey.

Male genitalia (Figs 6-8): Uncus with two long socii, basally broad, narrower to truncated tip, tegumen broad, laterally the long thin saccus deep impressed; valva with long transtilla, costa straight, ventral edge convexe, valva at $1 / 2$ broadest, narrower to rounded apex; phallus as long as valva, narrow, with some very small spines subapically.

Female genitalia (Fig. 9): Ventral branch of apophysae ends in a nearly square plate, ostium cup-shaped, apically with fine granulate sclerotization, first part of ductus bursae strong sclerotized.

Etymology: Named after the narrow forewings.

\section{Neurothaumasia tunesiella sp. n.}

\section{Material:}

Holotype o`, “Tunisia, Nefta area, 1.-4.v.1988, Zool. Mus. Copenhagen Exp.;”“Gen.präp. [genitalia slide] Gaed.[IKe] Nr. 3623;" "Holotypus o Neurothaumasia tunesiella sp. n. det. R. Gaedike 2011;"ZMUC. - Paratype: 1 ơ, "Tunisia, Nefta, 15.ix.1982, [leg.] Delmastro;" "Gen.präp. [genitalia slide] Gaed.[IKe] Nr. 2755;" Coll. Baldizzone.

\section{Description (Fig. 3):}

Wingspan 7-8 mm; head brush creamy, apically darker, scales from neck to insertion of antennae and above palpi flat, shining creamy; labial palpi outside light grey-brown, inside whitish, second segment apically with some bristles; antenna as long as forewing, scapus grey-brown, flagellum shining creamy; thorax shining creamy, tegulae somewhat darker; forewing narrow, without pattern, light greyish-brown, shining, dorsum on narrow stripe creamy; hindwing shining whitish.

Male genitalia (Figs 10-12): Uncus with two socii, basally broad, to apex narrower, with oblique truncated tip; tegumen nearly allways broad, saccus thin, as long as socii; valva with long curved transtilla, parallel, with rounded apex; phallus somewhat shorter as valva, narrow, without visible cornuti.

Female genitalia: Unknown.

Etymology: Named after the country of type location. 


\section{Meneessia minutella (PETERSEN, 1959)}

\section{Material:}

Tadzhikistan: 3 ㅇ ㅇ , Vachschskaja dolina [Valley of Wachsch], Kurgan-Tjube, 1., 4., 25.ix.1951, leg. Shchetrin; ZMHB. First country record, the species was previously known only from Afghanistan (type locality), Pakistan and Turkmenistan.

\section{Matratinea rufulicaput SzIRAKI \& SzÖCS, 1990}

\section{Material:}

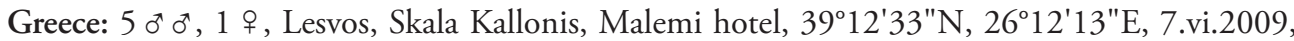
leg. L. Kaila \& J. Kullberg; FMNH; Bulgaria: 1 ㅇ, Bulgaria or., Vlas, 16-19.vii.1981, leg. V. Zouhar; ZFMK; First country record. Hitherto known only from Hungary (type location) and from Greece (Lesvos island).

The series from Lesvos contains also a previously unknown female, which is described for the first time below (Fig. 13): Ventral branch of apophysae anteriores ends band-shaped, with fine lenghtswise sclerotization, lateral of ostium convexe, bristled; first part of ductus bursae broad, stronger sklerotized as second part.

\section{Infurcitinea nigropluviella (WALSINGHAM, 1907)}

\section{Material:}

Iran: 1 o $^{\star}$, Fars, 10 km S Deh Bid, 2000 m, 14.vi.1996, leg. R. Linnavuori; FMNH. First record from Central Asia, previously known from Northern Africa (Tunisia, Algeria), from Greece, Cyprus, and from Turkey.

\section{Infurcitinea turcica PETERSEN, 1968}

\section{Material:}

Greece: $20^{\star} 0^{\star}$, Lesvos, NR near Keramia, 390 $08^{\prime} 07^{\prime \prime N}, 26^{\circ} 26^{\prime} 08^{\prime \prime E}, 3.10 . v i .2009$, leg. L. KaILA \& J. Kullberg; FMNH; SDEI; $10^{*}$, Lesvos, Skala Kallonis, Malemi hotel, 39 $12^{\prime} 33^{\prime \prime N}$, 261'ㄹ'13"E, 7.vi.2009, leg. L. Kaila \& J. KullberG; FMNH: First record from Europe. Hitherto known only from Turkey.

\section{Infurcitinea vanderwolfi GAEDIKE, 1997}

\section{Material:}

Croatia: $1 \sigma^{-}$, Konjevrate, 11.vii.2007; leg. et coll. Richter. First country record. Hitherto known only from Greece. 


\section{Infurcitinea corleyi sp. $\mathrm{n}$.}

\section{Material:}

Holotype ơ, "Portugal, Montesinho, Trás-os-Montes, 9.vii.2009, leg. M. F. V. Corley;" "Gen. präp. [genitalia slide] GaEdike Nr. 7382;" "Holotypus ơ Infurcitinea corleyi sp. n., det. R. GaEdike

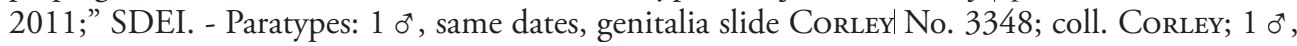
"Portugal, Lama Grande, Montesinho, Trás-os-Montes, 10.vii.2009, leg. M. F. V. Corley;" genitalia slide Corley No. 3283; coll. Corley; 1 specimen without abdomen, "Portugal, Poco do Inferno, Serra da Estrela, 12.vii.2009, leg. M. F. V. Corley; coll. Corley.

\section{Description (Fig. 4):}

Wingspan $8 \mathrm{~mm}$; head brush clay-brown, somewhat reddish, the area above palpi up to insertion of antennae lighter than the area above neck; antenna dark grey-brown; labial palpi inside whitish, outside dark grey-brown, second segment bristled; thorax and tegulae dark greybrown; forewing dark grey-brown with pattern of some whitish patches and stripes. Whitish are patches on dorsum at $1 / 3$, reaching cell and on beginn of fringe, a short stripe on costa at $1 / 2$ and a small hook-shaped stripe on costa before apex, fringe with dark scale-line; hindwing grey.

Male genitalia (Figs 14-16): Uncus narrow, tegumen lateral cloth-shaped enlarged, ventral very narrow, edged; valva basally rounded, basal edge stronger sclerotized, costal arm after 1/2 narrowed, the oval tip with numerous strong bristles; the two valvae ventrally connected with a hyaline skin with a field of very long bristles, phallus as long as valva, basally broad, rounded, bent to tip with two small spines.

Female genitalia: Unknown.

Etymology: Named after my collegue Martin F. V. CorLey, the collector of the type series.

\section{Remarks:}

Superficially similar to I. ignicomella, but the shape of genitalia distinguishes it clear.

\section{Stenoptinea cyaneimarmorella (MILLIÈRE, 1854)}

\section{Material:}

Spain: Canary Islands: 1 우 Tenerife, Las Moraditas, Bco de Taucho, 19.iii.2010, leg. et coll. WERno. First record for Canary Islands.

Previously known from nearly whole Europe, from Lebanon, Algeria, Tunisia and from Russian Far East.

\section{Ateliotum larseni sp. n.}

\section{Material:}

Holotype o", "Spain, Islas Canarias, Gran Canaria, Mogan, Soria, 5 km E., 800 m, 22.30.vii.1995, leg. K. Larsen;" "Holotypus o Ateliotum larseni sp. n., det. R. Gaedike 2011;" SDEI. - Paratypes: $24 \sigma^{\star} \sigma^{\star}, 2$ ㅜ, same dates as holotype; SDEI; coll. RoweCK; coll. Larsen; 6 o o $^{\star}$, "Spain, Islas Canarias, Gran Canaria, Mogan, La Playa de Tauro, 20.vii.1995, leg. 
K. Larsen;" SDEI; coll. Roweck; $10^{*}, 1$ ㅇ "Spain, Islas Canarias, Gran Canaria, Mogan, El Barranquillo, 24.vii.1995, leg. K. LARsEn;" SDEI; coll. Roweck; 18 ơ o , "Spain, Islas Canarias, Gran Canaria, Mogan, Barranco de Arguineguin, 21.vii.-1.viii.1995, leg. K. Larsen;” SDEI, coll. Roweck; 2 o $^{\star}$, "Spain, Islas Canarias, Gran Canaria, 800 m, Cueva de las Ninas, 29.vii.1995, leg. K. Larsen;" SDEI, coll. Roweck; 1 o", "Spain, Islas Canarias, Gran Canaria,

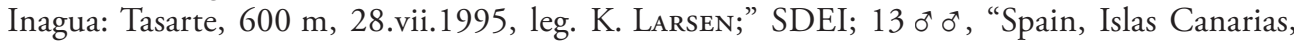
Gran Canaria, Maspalomas: Presa de Chamoriscán, 300 m, 27.vii.-1.viii.1995, leg. K. LARsen;" SDEI; coll. Roweck; 1 đ, "Canary Islands, Gran Canaria, Tejeda, 1500 m, 24.-27.i.1995, leg. J. Junnilainen;” coll. Baraniak.

\section{Description (Fig. 5):}

Wingspan 13-15 mm; head brush creamy grey, antenna grey, scapus somewhat darker as flagellum; labial palpi with same coloration as head brush, second segment outside dark grey-brown, scales more or less prolonged; thorax and tegulae grey-brown, thorax basally and tegulae apically lighter; forewing creamy to grey, with a pattern of dark grey-brown dots and patches: two more or less clear patches on beginning of cell and before the end; base of costa; from base to $1 / 2$ numerous thin strigulae, four short stripes on costa from $1 / 2$ to apex, some very small dots on base of fringe; the whole wing overlaid with scattered darker or brownish scales; hindwing grey.

Male genitalia (Figs 17-23): Uncus with two socii, inside, near base a pointed strong sclerotized tooth, tegumen ventrally prolonged into a long bifurcate saccus; valva short, more or less triangular with rounded apex, inside subapical with a strong sclerotized pointed tooth, transtilla narrow, long, phallus longer than uncus-tegumen-saccus, thin, basally rounded, at the beginning of second half outside with some small pointed thorns, subapical additional smaller thorns, on apex a bent pointed process, at crease a strong sclerotized hook, depending from preparation not everytime visible (see Figs 20-23).

Female genitalia (Fig. 24): Ostium clear impressed, laterally bristled rounded lobi, major part of ductus bursae with almost longitudinal sclerotizations, signum cone-shaped, with fine crossways sclerotizations (characteristic for the genus).

Etymology: Named after my colleague KNUd LARSEN, the collector of this new species.

\section{Remarks:}

Superficially similar to some other members of the genus (insulare, petrinellum), but clear different in the structure of the genitalia. The long bifurcate saccus and the phallus with the characteristic shape in male, and the sclerotized ductus bursae in female are unique in the genus.

\section{Anomalotinea gardesanella (HARTIG, 1950)}

A series of specimens from Greece (Lesvos Island) contains also a female, which allows to describe it for the first time (Figs 25-26):

Ostium deep impressed, with stronger sclerotized edge, first part of ductus bursae more or less stronger sclerotized, narrower to corpus bursae; the intersegmental skin bears small granular sclerotizations. 


\section{Elatobia fuliginosella (LIENIG \& ZELLER, 1846)}

\section{Material:}

Turkey: $1 \sigma^{\star}$, Gümüshane, Kösedagi Gecidi, 1850 m, 16.vii.2000; 1 o $^{\star}$, Adana, Saimbeyli, $18 \mathrm{~km} \mathrm{~N}, 1700 \mathrm{~m}, 6 . v i i i .1997$, leg. et coll. LARSEN. First country records.

Previously known from nearly whole Europe (except Balkan Peninsula), eastwards up to European Russia, outside of Europe known from Morocco, Tunisia and Iran, from Siberia up to Mongolia.

\section{Elatobia bugrai Косак, 1981}

The tineid material, kindly sent me for examination by my colleague KNUD LARSEN, contains a male of this species, from which were previously known only females. Following is given a description of the male genitalia (Figs 27-30):

Uncus parallel, apically truncated, with rounded edges, laterally on base a hook, curved apically; tegumen narrow, saccus very long; valva as long as uncus-tegumen, more or less parallel, costa straight, dorsal edge convexe, costa ends in pointed tip, basally the tip a sclerotized edge; phallus as long as uncus-tegumen-saccus, basally rounded, to apex narrower, with a row of appr. 15 strong sclerotized short hooks. VIII. Segment ventrally with stronger sclerotized apical edge, dorsally with a triangular sclerotization, basally with a long thin process. This structure is nearly the same as in fuliginosella.

The species is known only from Greece and Turkey.

\section{Tinea basifacsiella RAGONOT, 1895}

\section{Material:}

Bulgaria: $1 \sigma^{\star}$, Pirin, Sandanski, Ploski, 100 m, 17.-31.v.2010, leg. N. SAvenkov; Coll. Roweck. First country record.

Previously known from Mediterranean region (Iberian Peninsula through Italia to Greece), outside of Europe from North Africa (Morocco to Libya), from Turkey to Iran.

\section{Reference}

Osthelder, L. 1936: Lepidopteren-Fauna von Marasch in Türkisch-Nordsyrien (MicrolepidopterenFortsetzung). - Mitteilungen der Münchner Entomologischen Gesellschaft 25 (3) (1935): 67-90.

Author's address:

Dr. Reinhard Gaedike

Florusstraße 5

53225 Bonn

Germany

email: tinagma@msn.com
Subject editor:

O. Karsholt 

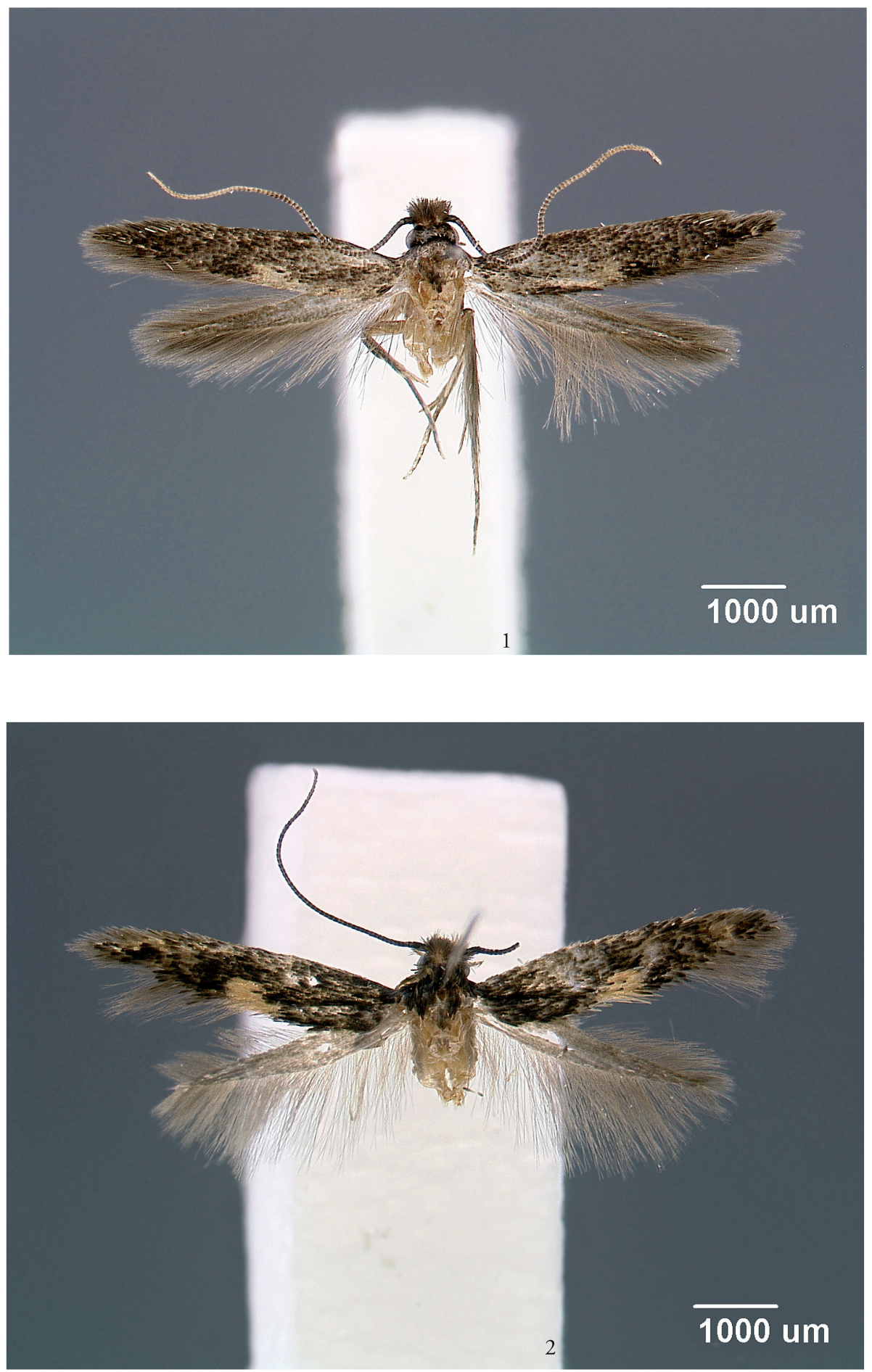

Figs 1-2: Neurothaumasia tenuipennella (1 - male; 2 - female). 


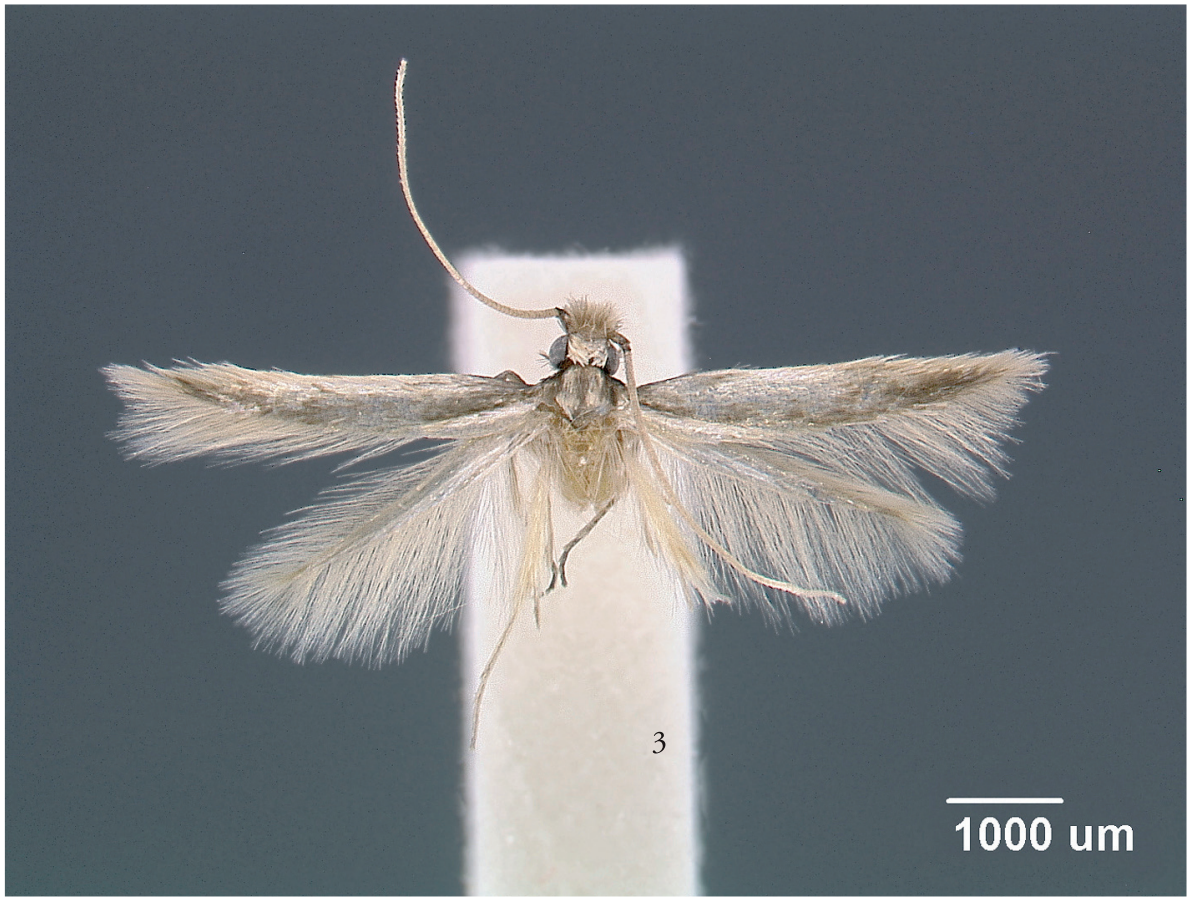

Fig. 3: Neurothaumasia tunesiella.

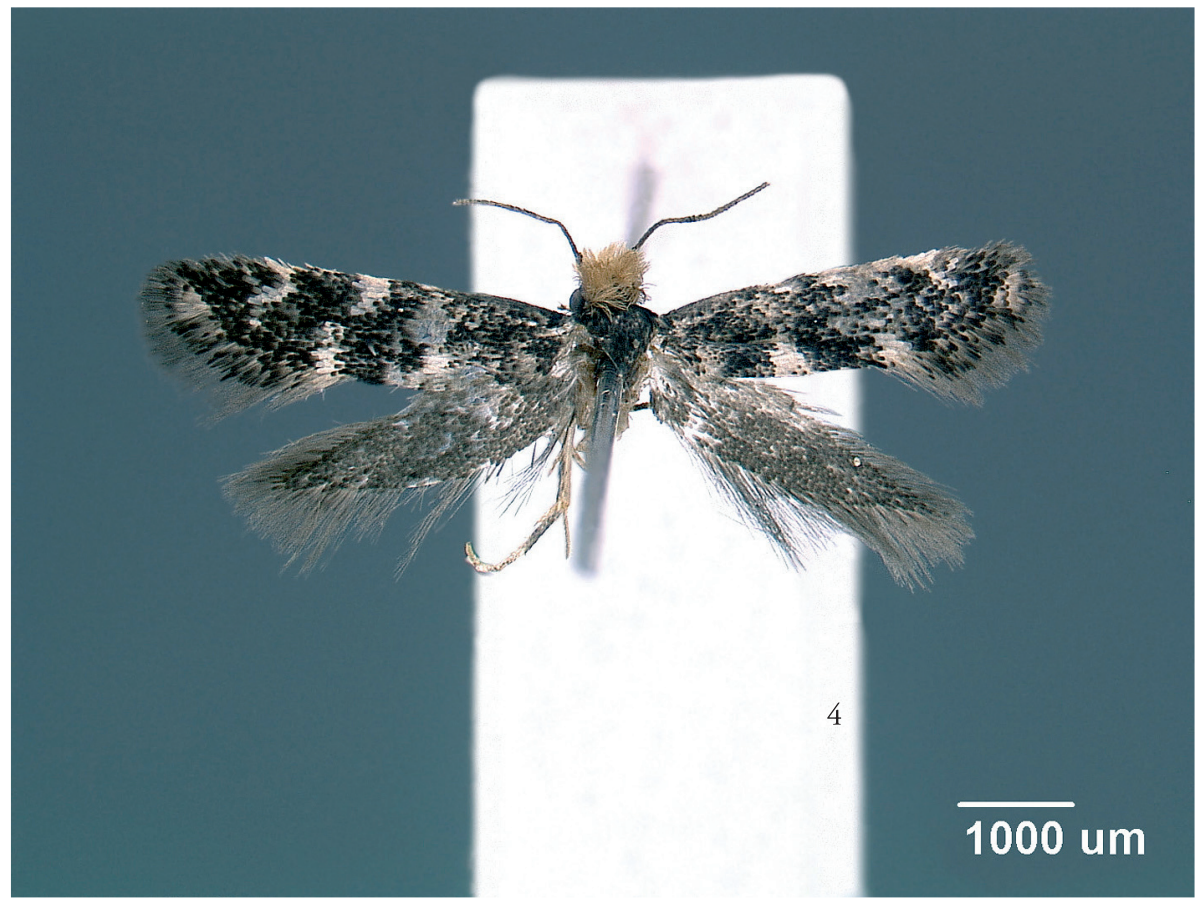

Fig. 4: Infurcitinea corleyi. 


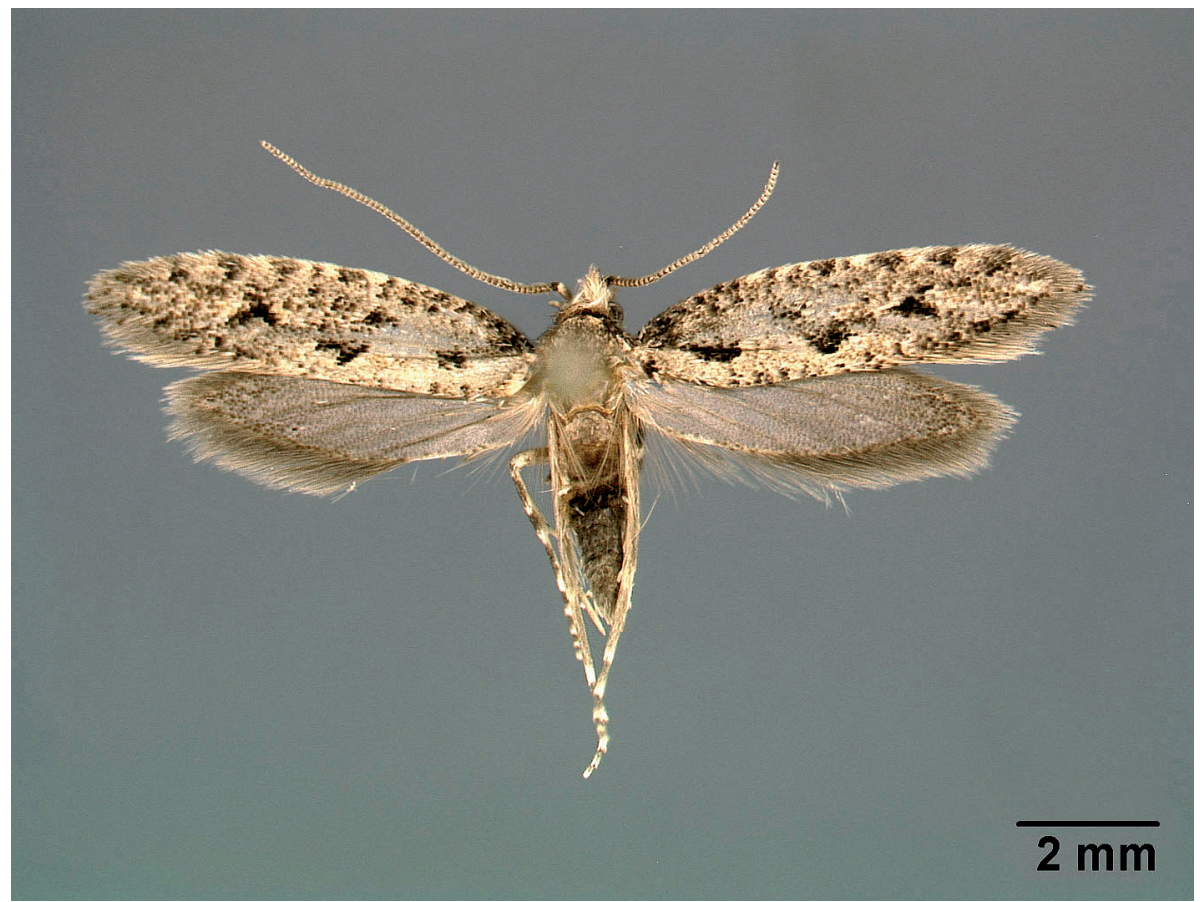

Fig. 5: Ateliotum larseni.
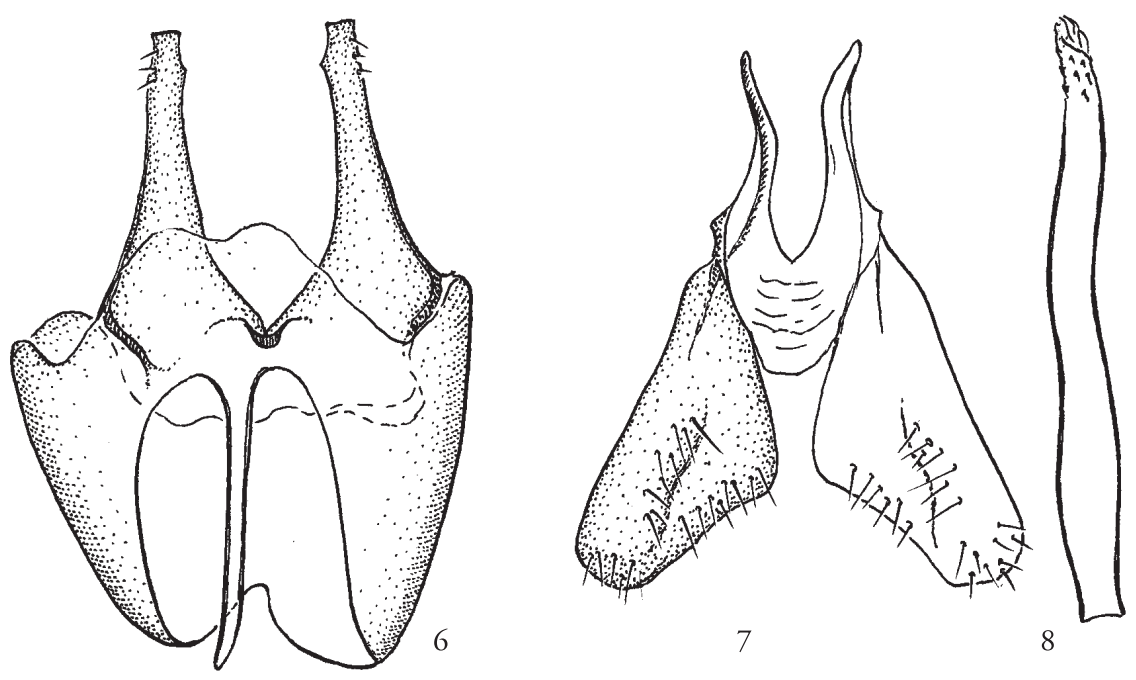

Figs 6-8: Neurothaumasia tenuipennella (o': 6 - uncus-tegumen; 7 - valvae; 8 - phallus). 


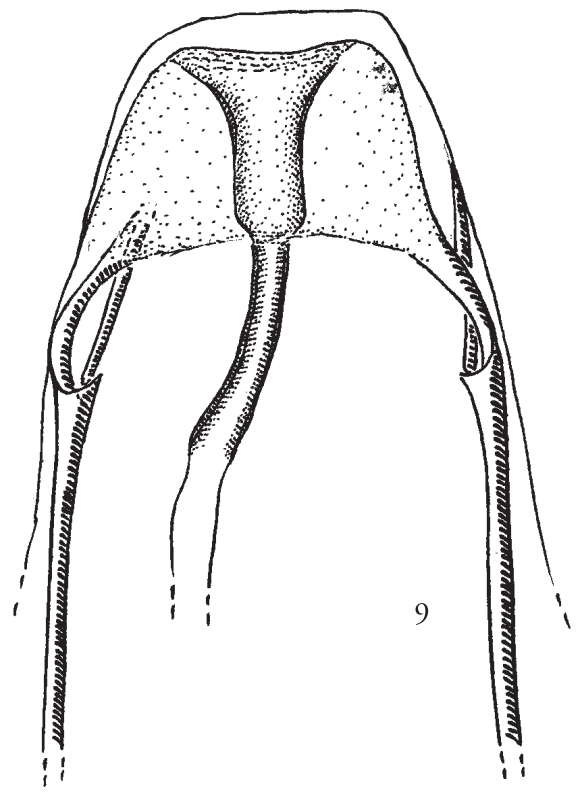

Fig. 9: Neurothaumasia tenuipennella, ㅇ. .

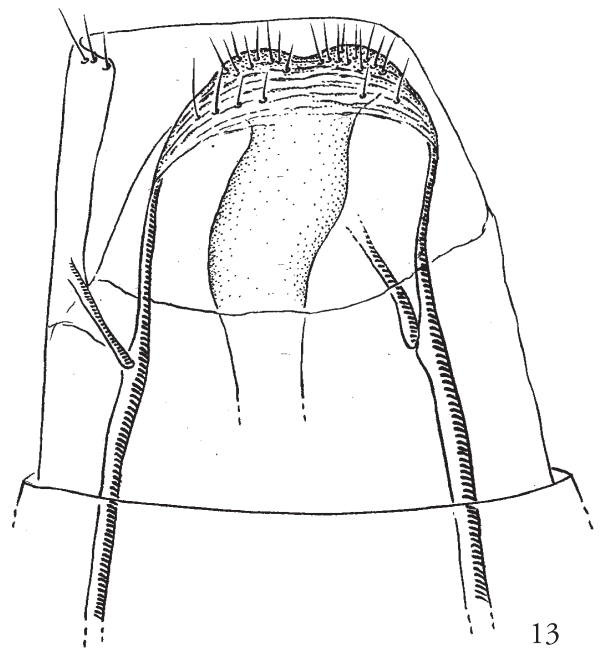

Fig. 13: Matratinea rufulicaput, ㅇ․
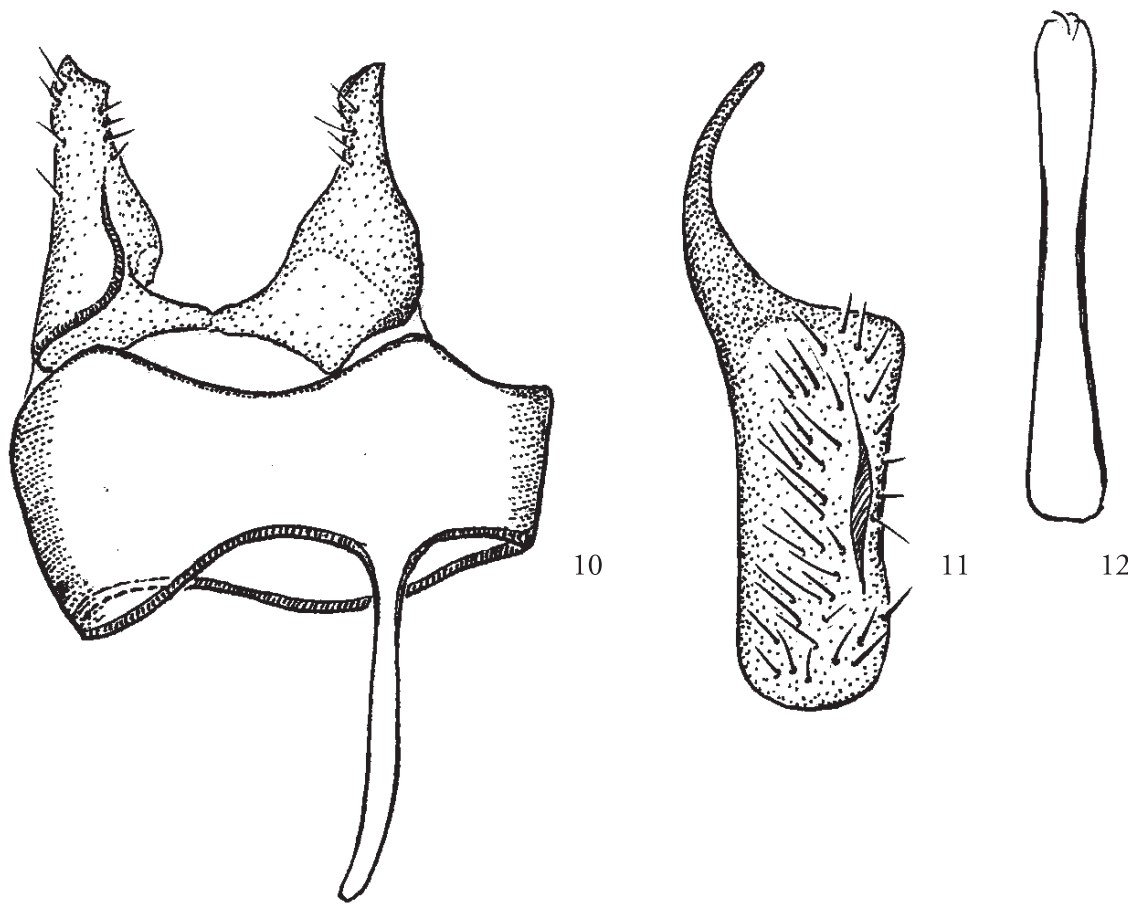

12

Figs 10-12: Neurothaumasia tunesiella, ${ }^{\star}$ (10 - uncus-tegumen; 11 - valva; 12 - phallus). 


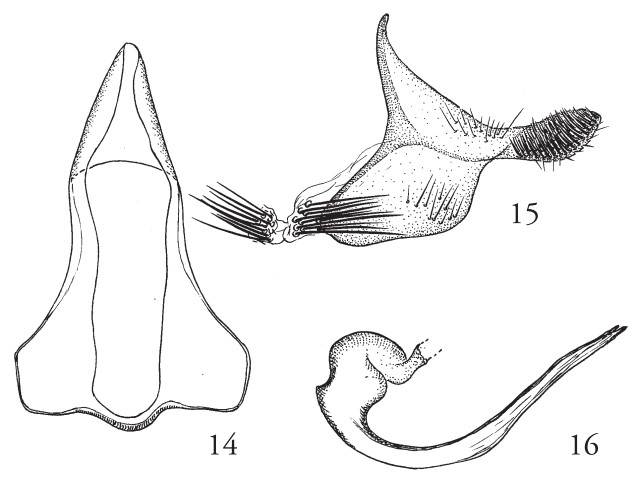

Figs 14-16: Infurcitinea corleyi, ơ : (14 - uncus-tegumen; 15 - valva; 16 - phallus).
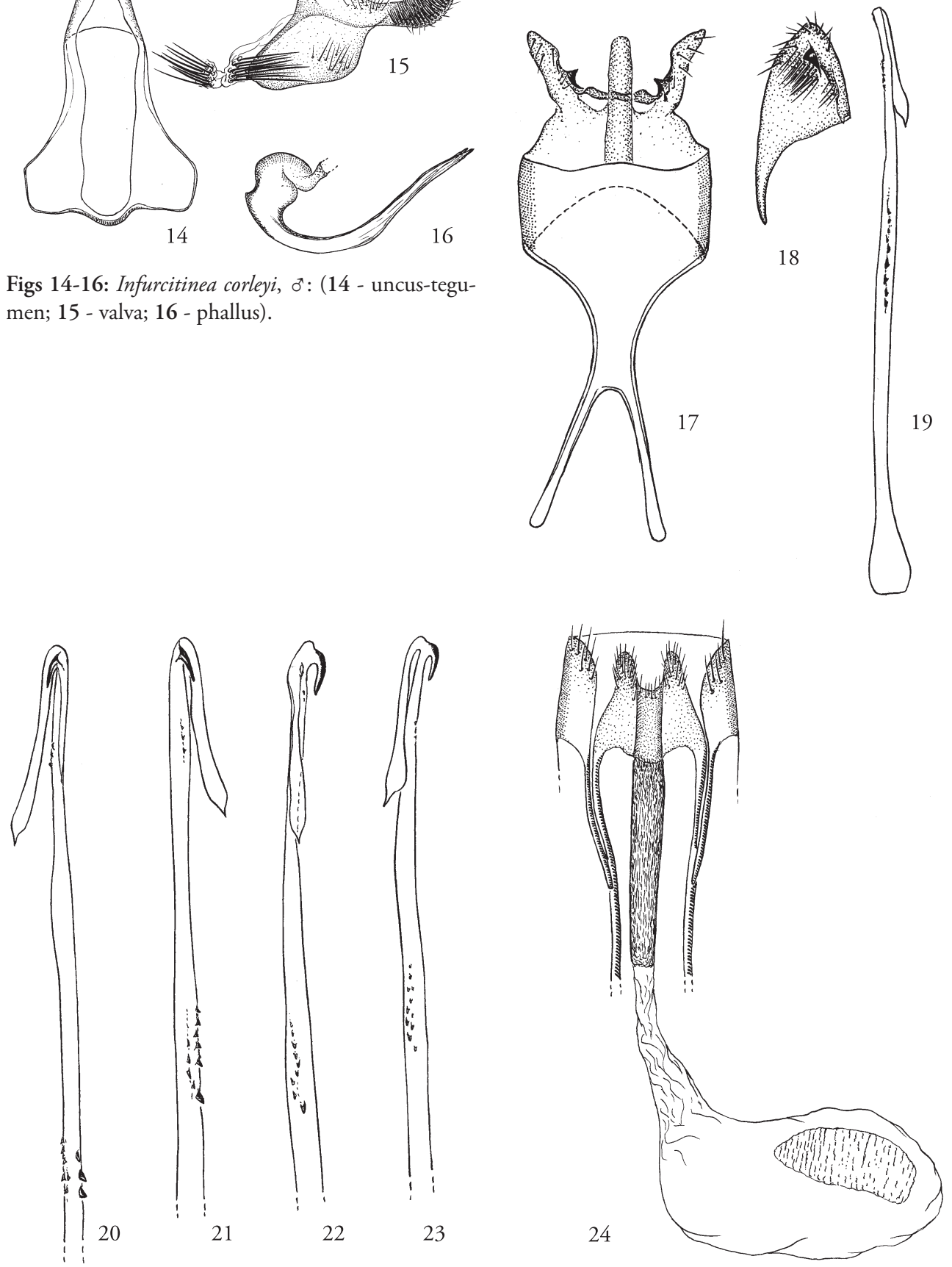

Figs 17-24: Ateliotum larseni ( $0^{\top}: 17$ - uncus-tegumen-saccus; 18 - valva; 19 - phallus; 20-23 - variability of phallus in higher magnification; $24-9$ ). 

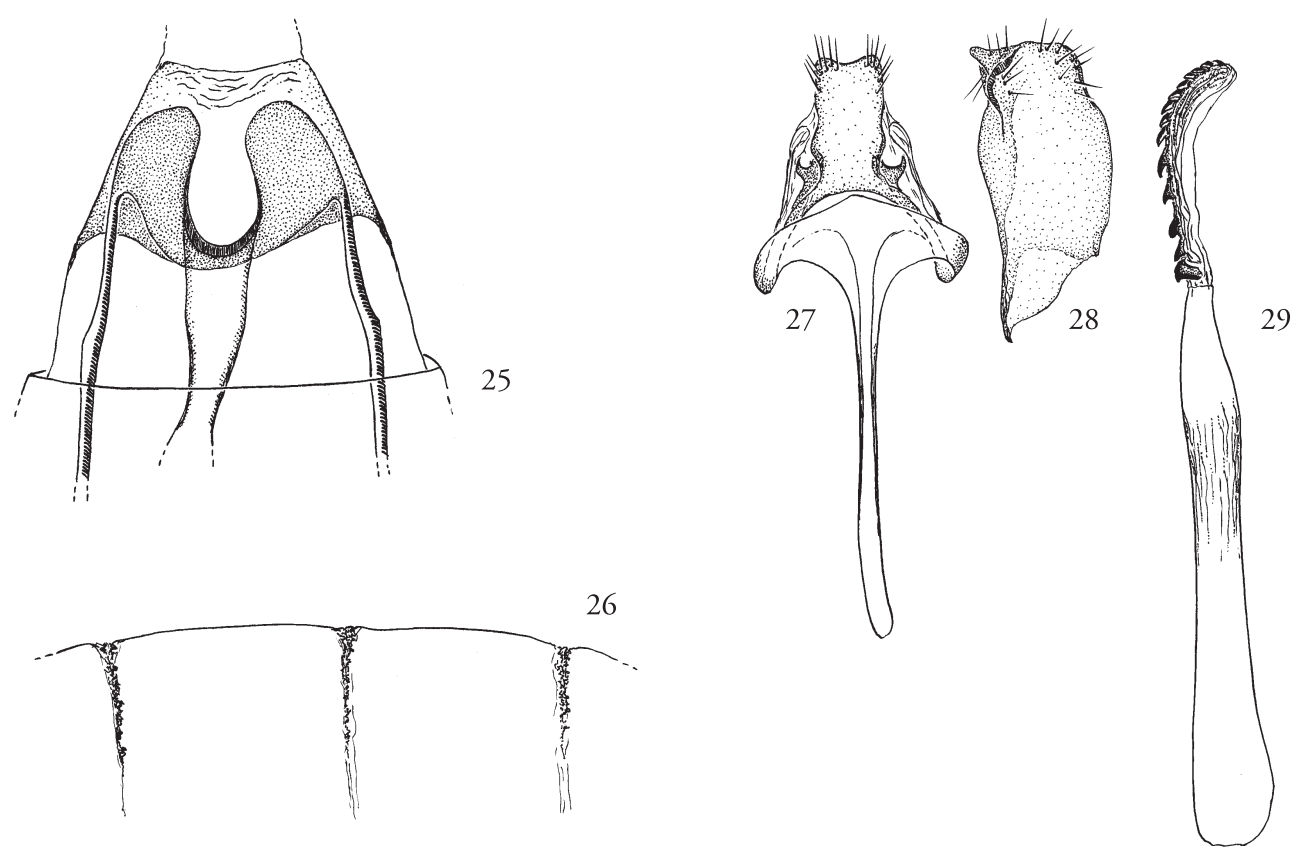

Figs 25-26: Anomalotinea gardesanella,, : (25 - ostium complex; 26 - intersegmental skin).

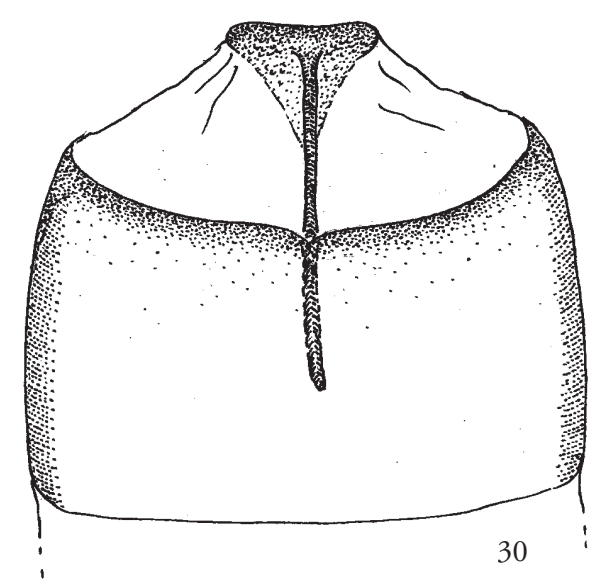

Figs 27-30: Elatobia bugrai, ơ: (27 - uncus-tegumensaccus; 28 - valva; 29 - phallus; 30 - VIII segment). 